Article

\title{
Antimicrobial Lavandulylated Flavonoids from a Sponge-Derived Streptomyces sp. G248 in East Vietnam Sea
}

\author{
Duc Danh Cao ${ }^{1,2} \mathbb{D}_{\text {, Thi Thanh Van Trinh }}{ }^{1}$, Huong Doan Thi Mai ${ }^{1,2}$, Van Nam Vu ${ }^{1}$, \\ Hong Minh Le ${ }^{1}$, Quyen Vu Thi ${ }^{1}$, Mai Anh Nguyen ${ }^{1}$, Thu Trang Duong ${ }^{1}$, Dang Thach Tran ${ }^{3}$, \\ Van Minh Chau ${ }^{1}$, Rui Ma ${ }^{4}$, Gauri Shetye ${ }^{4}$, Sanghyun Cho ${ }^{4}$, Brian T. Murphy ${ }^{5}$ and \\ Van Cuong Pham ${ }^{1, *}$
}

1 Advanced Center for Bioorganic Chemistry, Institute of Marine Biochemistry, Vietnam Academy of Science and Technology (VAST), Hanoi 11307, Vietnam; saola43@gmail.com (D.D.C.); trtvan76@yahoo.com (T.T.V.T.); huongdm@imbc.vast.vn (H.D.T.M.); vuvannam87@gmail.com (V.N.V.); lhminhbk@gmail.com (H.M.L.); svuquyen@yahoo.com (Q.V.T.); maianhhsb@gmail.com (M.A.N.); duongtrang2901@gmail.com (T.T.D.); cvminh@vast.vn (V.M.C.)

2 Faculty of Chemistry, Graduate University of Science and Technology, VAST, Hanoi 11307, Vietnam

3 Institute of Applied Science and Technology, University Industry of Vinh, Vinh 43115, Vietnam; trandangthach@yahoo.com.vn

4 Institute for Tuberculosis Research, College of Pharmacy, University of Illinois at Chicago, Chicago, IL 60612, USA; rma20@uic.edu (R.M.); gauris@uic.edu (G.S.); jkcno1@uic.edu (S.C.)

5 Department of Pharmaceutical Sciences, College of Pharmacy, University of Illinois at Chicago, Chicago, IL 60607, USA; btmurphy@uic.edu

* Correspondence: phamvc@imbc.vast.vn; Tel.: +84-2437-9170-49

Received: 16 August 2019; Accepted: 6 September 2019; Published: 10 September 2019

check for updates

\begin{abstract}
Three new lavandulylated flavonoids, (2S,2"S)-6-lavandulyl-7,4'-dimethoxy-5,2'dihydroxylflavanone (1), (2S,2"S)-6-lavandulyl-5,7,2',4'-tetrahydroxylflavanone (2), and (2"S)-5'lavandulyl-2'-methoxy-2,4,4',6'-tetrahydroxylchalcone (3), along with seven known compounds 4-10 were isolated from culture broth of Streptomyces sp. G248. Their structures were established by spectroscopic data analysis, including 1D and 2D nuclear magnetic resonance (NMR), and high-resolution electrospray ionization mass spectrometry (HR-ESI-MS). The absolute configurations of 1-3 were resolved by comparison of their experimental and calculated electronic circular dichroism spectra. Compounds 1-3 exhibited remarkable antimicrobial activity. Whereas, two known compounds 4 and 5 exhibited inhibitory activity against Mycobacterium tuberculosis H37Rv with minimum inhibitory concentration (MIC) values of $6.0 \mu \mathrm{g} / \mathrm{mL}$ and $11.1 \mu \mathrm{g} / \mathrm{mL}$, respectively.
\end{abstract}

Keywords: actinomycete; Streptomyces; flavonoid; anti-tuberculosis; anti-microbial; cytotoxicity

\section{Introduction}

Marine sponges are known to harbor diverse microbial communities [1-4]. These marine-derived microorganisms have been a rich source for a multitude of biomedically relevant secondary metabolites [5-7]. Among actinomycetes, the genus Streptomyces is considered to be the most prolific producer of secondary metabolites for medical, agricultural and veterinary usage [8-10]. Previous reports showed that the Streptomyces genus has the ability to produce a variety of secondary metabolites with various activities, including antimicrobial, anticancer, and antiparasitic [11-13].

In search of bioactive metabolites from marine-derived actinomycetes, the Streptomyces sp. G248 (Figures S1-S3), from the sponge Halichondria panicea (Pallas, 1766) collected from the coast of Da 
Nang in Vietnam was selected as its extract displayed antimicrobial activity against pathogenic Enterococcus faecalis and Staphylococcus aureus strains. Herein, we report the isolation and structural characterization of three new lavanludylated flavonoids (1-3) and seven known compounds (4-10) from the fermentation broth of the Streptomyces sp. G248 (Figure 1). Furthermore, their antimicrobial and cytotoxic activity evaluations were also discussed.<smiles>C=C(C)C(C)=CCC(CC=C(C)C)c1c(O)cc2c(c1O)C(=O)C[C@@H](c1ccc(O)cc1O)O2</smiles><smiles>COc1ccc([C@H]2CC(=O)c3c(cc(O)c(CC=C(C)C)c3O)O2)cc1</smiles><smiles>CC(C)CC1NC(=O)C2CCCN2C1=O</smiles><smiles>[R]c1ccc(C[C@H]2NC(=O)[C@@H]3CCCN3C2=O)cc1</smiles><smiles>Nc1ncnc2[nH]cnc12</smiles>

Figure 1. Structures of compounds 1-10.

\section{Results and Discussion}

\subsection{Isolation and Structural Elucidation}

Culture broth solution (50 L) of Streptomyces sp. G248 was desalted by an Amberlite XAD-16 column, eluting with distilled water, then with methanol. The methanol solution was concentrated under reduced pressure. The crude extract $(12.6 \mathrm{~g})$ was purified by repeated open column chromatography to give compounds 1-10.

Compound 1 was isolated as yellow amorphous solid, and was optically active $\left\{[\alpha]^{25} \mathrm{D}-5\right.$ (c 0.176 , $\mathrm{MeOH})\}$. Its positive HR-ESI mass spectrum (Figure S15) exhibited the proton adduct ion $[\mathrm{M}+\mathrm{H}]^{+}$at $m / z 453.2270$ (calcd. for $\mathrm{C}_{27} \mathrm{H}_{33} \mathrm{O}_{6}, 453.2277$ ) which, together with ${ }^{13} \mathrm{C}$ NMR data, is consistent with the molecular formula of $\mathrm{C}_{27} \mathrm{H}_{32} \mathrm{O}_{6}$. The IR spectrum (Figure S16) indicated the absorption bands at $v_{\max } 3366 \mathrm{~cm}^{-1}(\mathrm{OH})$ and $1696 \mathrm{~cm}^{-1},(\mathrm{C}=\mathrm{O})$ functionalities. In the ${ }^{1} \mathrm{H}$ NMR spectrum (Figure S9), the presence of an ABX system at $\delta_{\mathrm{H}} 6.49\left(\mathrm{~d}, J=2.3 \mathrm{~Hz}, \mathrm{H}-3^{\prime}\right), 6.47\left(\mathrm{dd}, J=2.3,8.5 \mathrm{~Hz}, \mathrm{H}-5^{\prime}\right)$ and $7.38\left(\mathrm{~d}, J=8.5 \mathrm{~Hz}, \mathrm{H}-6^{\prime}\right)$, and a singlet proton at $\delta_{\mathrm{H}} 6.12(\mathrm{~s}, \mathrm{H}-8)$ was observed at the aromatic region. Additionally, the resonances of protons at $\delta_{\mathrm{H}} 5.55(\mathrm{H}-2), 4.96\left(\mathrm{H}-4^{\prime \prime}\right), 4.52\left(\mathrm{H}_{\mathrm{a}}-9^{\prime \prime}\right)$ and $4.59\left(\mathrm{H}_{\mathrm{b}}-9^{\prime \prime}\right)$, two methoxy groups at $\delta_{\mathrm{H}} 3.82$ and 3.83 , three singlet methyls at $\delta_{\mathrm{H}} 1.48\left(\mathrm{CH}_{3}-6^{\prime \prime}\right), 1.57\left(\mathrm{CH}_{3}-7^{\prime \prime}\right)$ and $1.64\left(\mathrm{CH}_{3}-10^{\prime \prime}\right)$ and seven aliphatic protons from 1.80 to $3.10 \mathrm{ppm}$ were also noted. Analysis of the ${ }^{13} \mathrm{C}$ NMR spectrum (Figure S10) with the aid of an HSQC experiment (Figure S12) revealed 27 carbon resonances for 1 , including one ketone group $\left(\delta_{C} 193.6, C-4\right)$, ten $\mathrm{sp}^{2}$ quaternary carbons, five $\mathrm{sp}^{2}$ methines, one $\mathrm{sp}^{2}$ methylene, two $\mathrm{sp}^{3}$ methines, three $\mathrm{sp}^{3}$ methylenes, two methoxy groups and three methyls. Beside the aromatic ABX system, two other spin-spin coupling systems were revealed from the COSY spectrum (Figure S11): $\mathrm{H}-2\left(\delta_{\mathrm{H}} 5.55\right) / \mathrm{CH}_{2}-3\left(\delta_{\mathrm{H}} 2.67\right.$ and 2.89$)(\mathrm{I})$, and $\mathrm{CH}_{2}-1$ " $\left(\delta_{\mathrm{H}} 2.63\right) / \mathrm{H}-2$ " $\left(\delta_{\mathrm{H}} 2.50\right) / \mathrm{CH}_{2}-3^{\prime \prime}\left(\delta_{\mathrm{H}} 2.02\right) / \mathrm{H}-4 "{ }^{\prime \prime}\left(\delta_{\mathrm{H}} 4.96\right)(\mathrm{II})$. The chemical shifts of carbons at $\delta_{\mathrm{C}} 75.0(\mathrm{C}-2), 160.1$ $\left(\mathrm{C}-2^{\prime}\right), 159.0\left(\mathrm{C}-4^{\prime}\right), 164.7$ (C-5), 165.4 (C-7) and 161.9 (C-9) suggested their linkage to oxygen (Table 1). In the HMBC spectrum (Figure S13), cross-peaks of C-2" $\left(\delta_{\mathrm{C}} 48.2\right)$ with protons of $\mathrm{CH}_{3}-10^{\prime \prime}\left(\delta_{\mathrm{H}} 1.64\right)$ and $\mathrm{CH}_{2}-9^{\prime \prime}\left(\delta_{\mathrm{H}} 4.52\right.$ and 4.59$)$, and those of $\mathrm{C}-8^{\prime \prime}\left(\delta_{\mathrm{C}} 149.8\right)$ with protons of $\mathrm{CH}_{3}-10^{\prime \prime}$ indicated the linkage of the substructure II with the isopropenyl group through the $\mathrm{C}-2^{\prime \prime} / \mathrm{C}-8^{\prime \prime}$ bond. Additionally, HMBC correlations of C-4" $\left(\delta_{C} 124.8\right)$ and C- $5^{\prime \prime}\left(\delta_{C} 132.0\right)$ with protons of $\mathrm{CH}_{3}-6^{\prime \prime}\left(\delta_{\mathrm{H}} 1.48\right)$ and $\mathrm{CH}_{3}-7^{\prime \prime}$ $\left(\delta_{\mathrm{H}} 1.57\right)$ defined the presence of a lavandulyl group in the structure of 1 . The presence of the A-ring 
was confirmed by the HMBC cross-peaks of $\mathrm{H}-8\left(\delta_{\mathrm{H}} 6.12\right)$ with $\mathrm{C}-6\left(\delta_{\mathrm{C}} 109.6\right), \mathrm{C}-7\left(\delta_{\mathrm{C}} 165.4\right), \mathrm{C}-9\left(\delta_{\mathrm{C}}\right.$ $161.9)$ and $\mathrm{C}-10\left(\delta_{C}\right.$ 105.7). The aromatic $\mathrm{ABX}$ system (B-ring) was confirmed by HMBC correlations of $\mathrm{H}-3^{\prime}\left(\delta_{\mathrm{H}} 6.49\right)$ with $\mathrm{C}-1^{\prime}\left(\delta_{\mathrm{C}} 119.7\right), \mathrm{C}-2^{\prime}\left(\delta_{\mathrm{C}} 160.1\right), \mathrm{C}-4^{\prime}\left(\delta_{\mathrm{C}} 159.0\right)$ and $\mathrm{C}-5^{\prime}\left(\delta_{\mathrm{C}} 108.1\right)$. The connection of $C-2$ with the B-ring at $C-1^{\prime}$ was revealed by cross-peaks of $H-2\left(\delta_{H} 5.55\right)$ with $C-1^{\prime}\left(\delta_{C} 119.7\right)$ and $C-6^{\prime}$ $\left(\delta_{C} 128.5\right)$. The spectral features of coupling systems I and the carbonyl group deduced from HMBC signals indicated structural similarity of $\mathbf{1}$ to flavanone compounds. Furthermore, the attachment of the lavandulyl group to the A-ring at C- 6 via C-6/C-1" linkage was revealed by HMBC cross-peaks of the protons of $\mathrm{CH}_{2}-1$ " $\left(\delta_{\mathrm{H}} 2.63\right)$ with $\mathrm{C}-5\left(\delta_{\mathrm{C}} 164.7\right), \mathrm{C}-6\left(\delta_{\mathrm{C}} 109.6\right)$ and $\mathrm{C}-7\left(\delta_{\mathrm{C}} 165.4\right)$, and was supported by the correlations of the methoxy protons at $\mathrm{C}-7$ with the protons of $\left.\mathrm{CH}_{2}-1^{\prime \prime}\right)$ in the ROESY spectrum of 1 (Figure S14). Finally, the two methoxy groups at $\delta_{\mathrm{H}} 3.82$ and 3.83 were attached to C-7 and C- $4^{\prime}$ as indicated by their correlations in the HMBC spectrum (Figure 2). Complete analyses of 2D NMR spectra established the planar structure of $\mathbf{1}$ as 6-lavandulyl-7, $4^{\prime}$-dimethoxy-5,2'-dihydroxylflavanone.

Table 1. NMR data for compounds $1-3\left(\mathrm{CD}_{3} \mathrm{OD},{ }^{1} \mathrm{H}: 500 \mathrm{MHz},{ }^{13} \mathrm{C}: 125 \mathrm{MHz}\right)$.

\begin{tabular}{|c|c|c|c|c|c|c|}
\hline \multirow[b]{2}{*}{$\mathbf{N}$} & \multicolumn{2}{|r|}{1} & \multicolumn{2}{|r|}{2} & \multicolumn{2}{|r|}{3} \\
\hline & $\delta_{C}$ & $\delta_{\mathrm{H}}$ mult. $(J$ in $\mathrm{Hz})$ & $\delta_{C}$ & $\delta_{\mathrm{H}}$ mult. $(J$ in $\mathrm{Hz})$ & $\delta_{C}$ & $\delta_{H}$ mult. $(J$ in $\mathrm{Hz})$ \\
\hline 1 & - & - & - & - & 116.3 & - \\
\hline 2 & 75.0 & $5.55 \mathrm{dd}(2.5,13.5)$ & 75.8 & $5.58 \mathrm{dd}(3.0,13.0)$ & 160.3 & - \\
\hline 3 & 45.4 & $\begin{array}{l}2.89 \mathrm{dd}(13.5,17.0) \\
2.67 \mathrm{dd}(2.5,17.0)\end{array}$ & 43.3 & $\begin{array}{c}2.99 \mathrm{dd}(13.0,17.0) \\
2.75 \mathrm{dd}(3.0,17.0)\end{array}$ & 103.7 & 6.35 br.s \\
\hline 4 & 193.6 & - & 198.9 & - & 162.4 & - \\
\hline 5 & 164.7 & - & 162.6 & - & 109.0 & $6.36 \mathrm{dd}(2.0,8.0)$ \\
\hline 6 & 109.6 & - & 108.7 & - & 131.6 & $7.41 \mathrm{~d}(8.0)$ \\
\hline 7 & 165.4 & - & 167.0 & - & - & - \\
\hline 8 & 93.6 & $6.12 \mathrm{~s}$ & 96.4 & $5.93 \mathrm{~s}$ & - & - \\
\hline 9 & 161.9 & - & 163.2 & - & - & - \\
\hline 10 & 105.7 & - & 103.2 & - & - & - \\
\hline $1^{\prime}$ & 119.7 & - & 118.4 & - & 106.5 & - \\
\hline $2^{\prime}$ & 160.1 & - & 156.7 & - & 162.3 & - \\
\hline $3^{\prime}$ & 99.8 & $6.49 \mathrm{~d}(2.3)$ & 103.4 & $6.36 \mathrm{~d}(2.5)$ & 91.6 & $6.02 \mathrm{~s}$ \\
\hline $4^{\prime}$ & 159.0 & - & 159.6 & - & 164.1 & - \\
\hline $5^{\prime}$ & 108.1 & $6.47 \mathrm{dd}(2.3,8.5)$ & 107.7 & $6.37 \mathrm{dd}(2.0,8.5)$ & 108.9 & - \\
\hline $6^{\prime}$ & 128.5 & $7.38 \mathrm{~d}(8.5)$ & 128.6 & $7.32 \mathrm{~d}(8.5)$ & 166.6 & - \\
\hline $1^{\prime \prime}$ & 28.2 & $2.63 \mathrm{~m}$ & 28.0 & $2.60 \mathrm{~m}$ & 28.2 & $2.65 \mathrm{~m}$ \\
\hline $2^{\prime \prime}$ & 48.2 & $2.50 \mathrm{~m}$ & 48.4 & $2.49 \mathrm{~m}$ & 48.0 & $2.57 \mathrm{~m}$ \\
\hline $3^{\prime \prime}$ & 32.3 & $2.02 \mathrm{~m}$ & 32.3 & $2.01 \mathrm{~m}$ & 32.4 & $2.09 \mathrm{~m}$ \\
\hline $4^{\prime \prime}$ & 124.8 & $4.96 \mathrm{t}(5.5)$ & 124.8 & $4.99 \mathrm{t}(5.5)$ & 125.0 & $5.06 \mathrm{td}(1.0,6.5)$ \\
\hline $5^{\prime \prime}$ & 132.0 & - & 132.0 & - & 131.8 & - \\
\hline $6^{\prime \prime}$ & 17.8 & $1.48 \mathrm{~s}$ & 17.8 & $1.50 \mathrm{~s}$ & 17.9 & $1.58 \mathrm{~s}$ \\
\hline $7^{\prime \prime}$ & 25.8 & $1.57 \mathrm{~s}$ & 25.8 & $1.59 \mathrm{~s}$ & 25.9 & $1.65 \mathrm{~s}$ \\
\hline $8^{\prime \prime}$ & 149.8 & - & 149.8 & - & 149.9 & - \\
\hline $9 "$ & 111.2 & $\begin{array}{l}4.52 \mathrm{~s} \\
4.59 \mathrm{~s}\end{array}$ & 111.1 & $\begin{array}{l}4.54 \mathrm{br} \mathrm{s} \\
4.60 \mathrm{br} \mathrm{s}\end{array}$ & 111.1 & $\begin{array}{l}4.61 \mathrm{br} \mathrm{s} \\
4.55 \mathrm{br} \mathrm{s}\end{array}$ \\
\hline $10^{\prime \prime}$ & 19.1 & $1.64 \mathrm{~s}$ & 19.2 & $1.65 \mathrm{~s}$ & 19.1 & $1.72 \mathrm{~s}$ \\
\hline $\mathrm{OMe}$ & 55.9 & $3.82 \mathrm{~s}$ & - & - & - & - \\
\hline $\mathrm{OMe}$ & 55.9 & $3.83 \mathrm{~s}$ & - & - & 56.1 & 3.91 \\
\hline$\alpha$ & - & - & - & - & 125.4 & $7.95 \mathrm{~d}(16.0)$ \\
\hline$\beta$ & - & - & - & - & 139.8 & $8.02 \mathrm{~d}(16.0)$ \\
\hline$\gamma$ & - & - & - & - & 194.8 & - \\
\hline
\end{tabular}




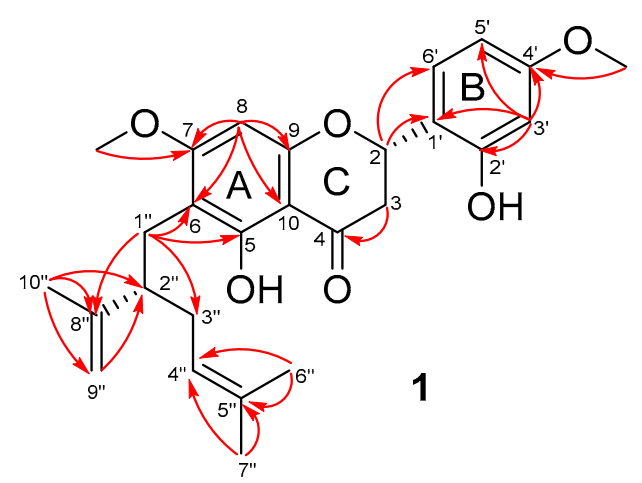

Figure 2. Key HMBC correlations of $\mathbf{1}$.

The 1D NMR spectra of compound 2 (Figures S18, S19 and S23) displayed resonances close to those of 1, except the absence of two methoxy groups. Complete analysis of 2D NMR spectra (Figures S20-S22 and S24) established the planar structure of 2 as 6-lavandulyl-5,7,2', $4^{\prime}$-tetrahydroxylflavanone (Figures S25 and S26), which shared the same planar structure with kushnol F, previously isolated from Sophora flavescens [14]. However, the absolute configuration of the chiral carbon C-2" has not been determined. Moreover, compound 2 had an optical rotation activity of $+3(c 0.2, \mathrm{MeOH})$, while this value is -59.8 ( $c 0.82, \mathrm{MeOH})$ for kushnol $\mathrm{F}$ [14].

Compound 3 was isolated as yellow amorphous solid and optically active $\left\{[\alpha]^{25} \mathrm{D}-1.8(c 0.54\right.$, $\mathrm{MeOH}$. Its positive HR-ESI-MS (Figure S35) showed the proton adduct ion $[\mathrm{M}+\mathrm{H}]^{+}$at $m / z 439.2117$ (calcd. for $\mathrm{C}_{26} \mathrm{H}_{31} \mathrm{O}_{6}, 439.2121$ ), consistent with a molecular formula of $\mathrm{C}_{26} \mathrm{H}_{30} \mathrm{O}_{6}$. The $1 \mathrm{D}$ NMR spectra of 3 (Figures S28, S29 and S33) exhibited the resonances for the A- and B-ring systems, and the lavandulyl group as found in compounds $\mathbf{1}$ and $\mathbf{2}$. However, signals of a $\mathrm{CH}=\mathrm{CH}$ system were observed in the 1D NMR spectra of 3 instead of resonances of the $\mathrm{CH}-2 / \mathrm{CH}_{2}-3$ spin system in the structures of $\mathbf{1}$ and 2.

Analysis of 2D NMR spectra of 3 (Figures S30-S32 and S34) confirmed the presence of the A and B-rings, and the lavandulyl substructure. Additionally, cross-peaks of $\mathrm{H}-\beta$ at $\delta_{\mathrm{H}} 8.02$ with $\mathrm{C}-2\left(\delta_{\mathrm{C}}\right.$ $160.3), C-6\left(\delta_{C} 131.6\right)$ and carbonyl carbon $C-\gamma\left(\delta_{C} 194.8\right)$ in the HMBC spectrum (Figure S32) indicated a chalcone skeleton for 3 (Figure S36). The methoxy group at C-2' was revealed by an HMBC correlation of $\mathrm{C}-2^{\prime}$ at $\delta_{\mathrm{C}} 162.3$ with the methoxy protons at $\delta_{\mathrm{H}} 3.91$ (Figure 3). As in the case of compounds $\mathbf{1}$ and $\mathbf{2}$, the location of the lavandulyl group at $C-5^{\prime}$ was established by the HMBC cross-peaks of $C-4^{\prime}\left(\delta_{C} 164.1\right)$, $\mathrm{C}-5^{\prime}\left(\delta_{\mathrm{C}} 108.9\right)$ and $\mathrm{C}-6^{\prime}\left(\delta_{\mathrm{C}} 166.6\right)$ with the protons of $\mathrm{CH}_{2}-1^{\prime \prime}\left(\delta_{\mathrm{H}} 2.65\right)$. The planar structure of 3 was finalized as $5^{\prime}$-lavandulyl-2'-methoxy-2,4,4', $6^{\prime}$-tetrahydroxylchalcone. This compound has the same planar structure as kuraridin, which was previously isolated from Albizzia julibrissin [15]. The optical rotation activity of kuraridin $\left\{[\alpha]_{\mathrm{D}}{ }^{20}+1.2(c 0.025, \mathrm{MeOH})\right\}[13]$ is opposite to that of compound 3 $\left\{[\alpha]_{\mathrm{D}}{ }^{25}-1.8(c 0.54, \mathrm{MeOH})\right\}$, and the absolute configuration at $\mathrm{C}-2$ " of kuraridin has not been reported.

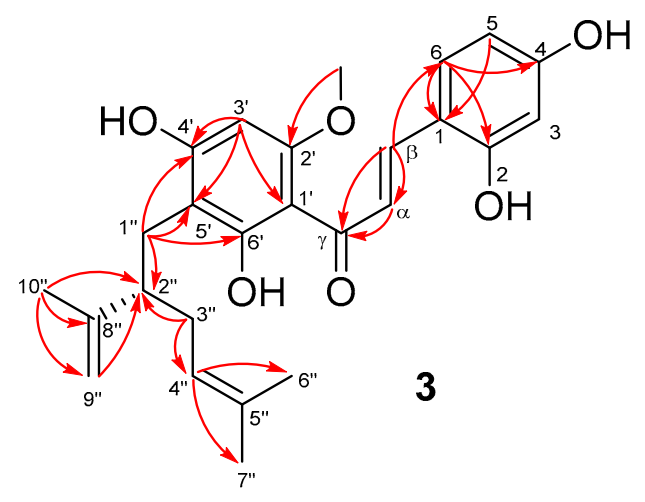

Figure 3. Selected HMBC correlations of 3. 
Absolute configurations of the compounds 1-3 were resolved by comparison of their experimental and calculated electronic circular dichroism (ECD) spectra [16,17]. The ECD quantum chemical calculations were performed using the Gaussian 09 software [18]. To obtain minimum energy conformers, geometry optimization of each possible isomer of these compounds was conducted (Tables S1-S5 and Figures S4-S8). The calculated ECD spectra of compounds 1-3 were generated using the time-dependent density functional method at the B3LYP/LanL2DZ level. Since the circular dichroism (CD) spectrum of compound 1 (Figure S17) had a positive Cotton effect at $337 \mathrm{~nm}(\Delta \varepsilon+3.6)$ and a negative Cotton effect at $291 \mathrm{~nm}(\Delta \varepsilon-7.7)$, the $S$-configuration was thus assigned for carbon C-2 of 1 [19]. The ECD spectra of the two possible diastereomers $\left(2 S, 2^{\prime \prime} S\right)-\mathbf{1}$ and $\left(2 S, 2^{\prime \prime} R\right)-\mathbf{1}$ were generated. As shown in Figure 4, the ECD spectrum of $\left(2 S, 2^{\prime \prime} S\right)-\mathbf{1}$ was similar as the experimental CD spectrum of $\mathbf{1}$, while an ECD spectrum of $\left(2 S, 2^{\prime \prime} R\right)-\mathbf{1}$ displayed the opposite Cotton effect at $233 \mathrm{~nm}$. The $S$-configuration was thus assigned for the chiral carbon C-2" of $\mathbf{1}$. Similarly, the $S$-configuration at C-2 was determined for 2 by the observation of a positive Cotton effect at $315 \mathrm{~nm}(\Delta \varepsilon+0.8)$ and a negative Cotton effect at $291 \mathrm{~nm}(\Delta \varepsilon-5.9)$ in the CD spectrum of 2 (Figure S27). By comparison of the ECD spectra of the two diastereomers $\left(2 S, 2^{\prime \prime} S\right)-2$ and $\left(2 S, 2^{\prime \prime} R\right)-2$ with the experimental CD spectrum of 2 (Figure 5), the $S$-configuration was also assigned for C-2" of 2 . The ECD of (2"S)-3 was in good agreement with the experimental CD spectrum of 3 (Figure S37). This observation allowed determination the $S$-configuration for carbon C-2" for $\mathbf{3}$ (Figure 6). Since the optical rotation activities of $\mathbf{2}$ and $\mathbf{3}$ are comparatively opposite with kushnol $\mathrm{F}$ and kuraridin, respectively, the absolute configuration at C-2" of kushnol $\mathrm{F}$ and kuraridin would most likely be $R$, however further experiments are required to state this definitively.

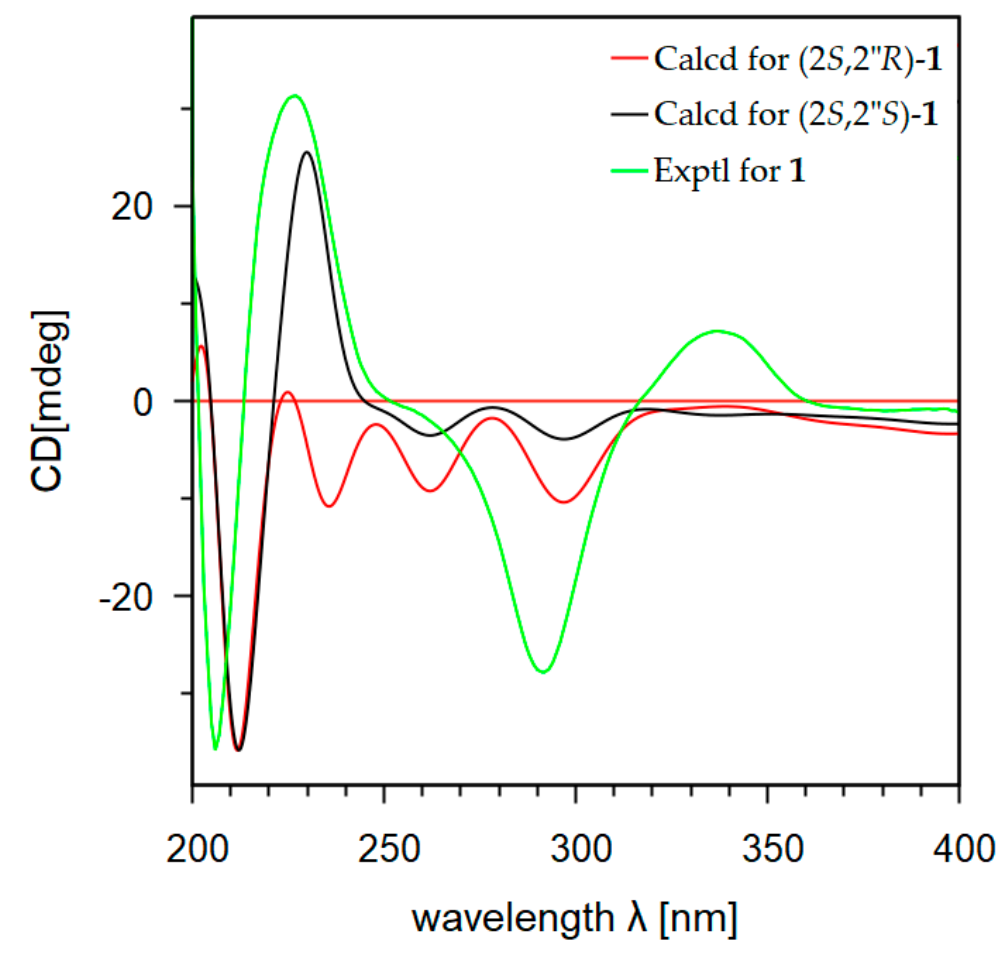

Figure 4. Calculated ECD and experimental CD spectra of $\mathbf{1}$. 


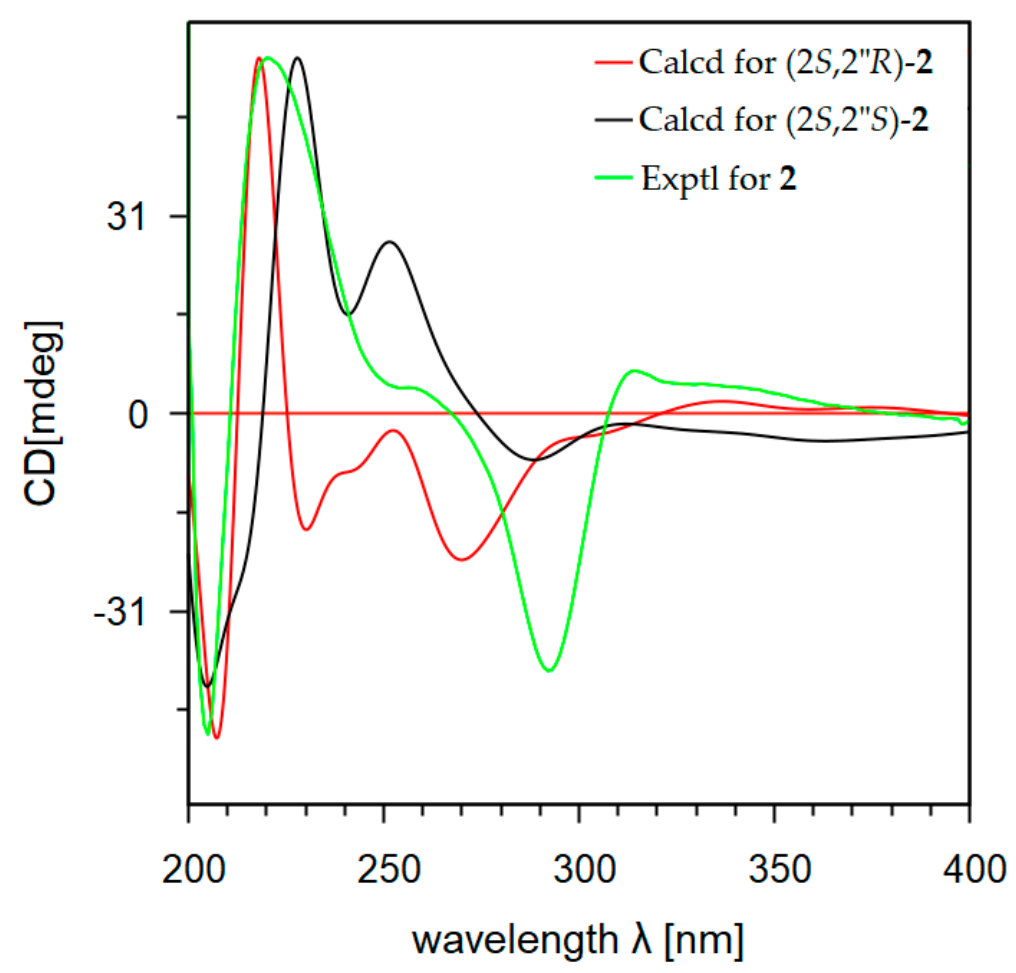

Figure 5. Calculated ECD and experimental CD spectra of 2.

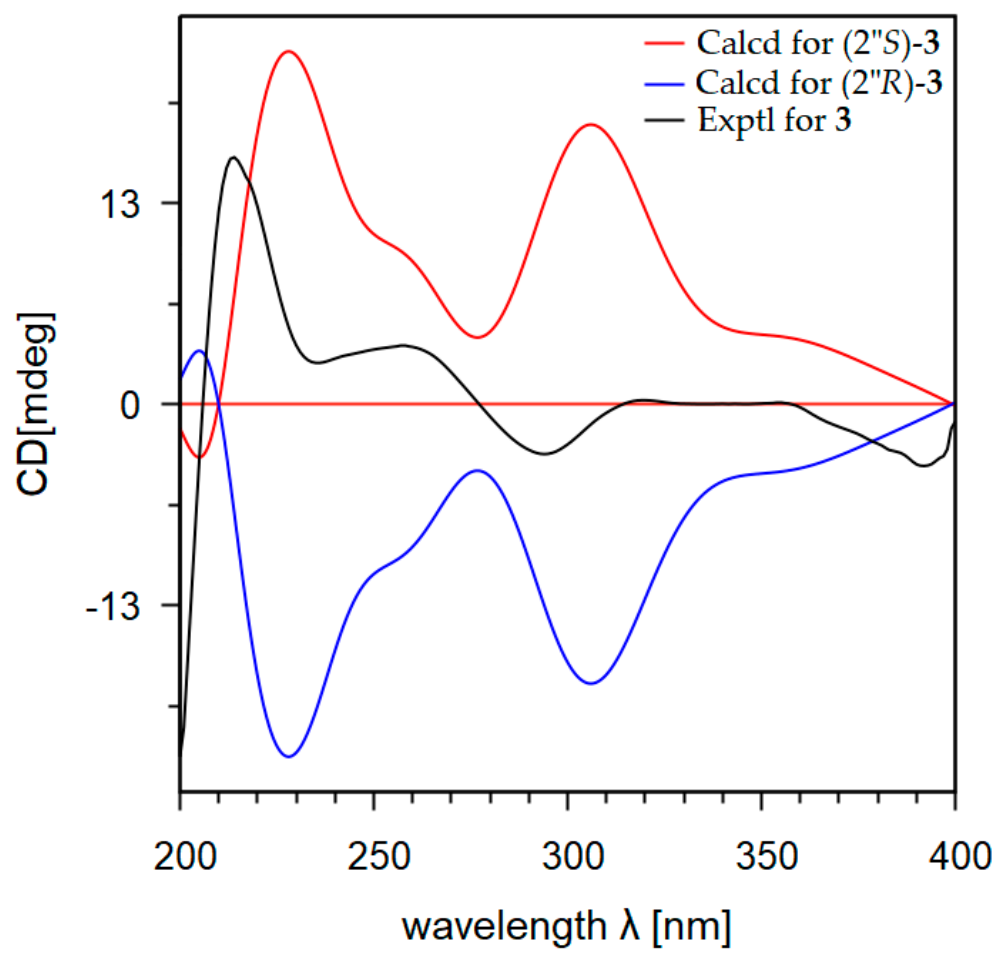

Figure 6. Calculated ECD and experimental CD spectra of 3.

Other known compounds, (2S,2"S)-6-lavandulyl-7-methoxy-5,2',4'-trihydroxylflavanone (4) [20], 6-prenyl-4'-methoxy-5,7-dihydroxylflavanone (5) [21], norharman ( $\beta$-carboline) (6) [22,23], cyclo-(Pro-Leu) (7) [24], cyclo-(Pro-Phe) (8) [25], cyclo-(Pro-Tyr) (9) [26], and adenine (10) [27] were also isolated and characterized from the culture broth of G248 strain. Their structures were established by spectroscopic data analysis and comparison with data reported in the literature. 


\subsection{Biological Activity}

Compounds 1-10 were evaluated for antibacterial activity against Enterococcus faecalis (ATCC13124), Staphylococcus aureus (ATCC25923), Bacillus cereus (ATCC13245), Escherichia coli (ATCC25922), Pseudomonas aeruginosa (ATCC27853), Salmonella enterica (ATCC12228), antiyeast activity against Candida albicans (ATCC1023), and in a separate experiment for anti-TB activity against Mycobacterium tuberculosis H37Rv. Compounds 1-3 exhibited antimicrobial activity, 2 exhibiting the most potent activity profile of the group. Compound 3 seems to have a broad spectrum of antimicrobial activity as it was active against all tested microbial strains (with the exception of M. tuberculosis H37Rv). Except against $E$. coli, compounds $\mathbf{1}$ and $\mathbf{2}$ showed significant inhibition activity against the remaining tested strains. The two known compounds 4 and 5 exhibited $\mathrm{IC}_{90}$ values of 6.0 and $11.1 \mu \mathrm{g} / \mathrm{mL}$ against $M$. tuberculosis H37Rv, respectively. This is the first report of the anti-TB activity for these two compounds (Table 2). Since, compound $\mathbf{4}$ exhibited anti-TB activity while $\mathbf{1}$ and $\mathbf{2}$ had no effect against M. tuberculosis, the methoxy group at C-7 and hydroxyl functionality at C- $4^{\prime}$ seem to be critical for the anti-TB activity of these compounds. Cytotoxicity evaluation indicated that compounds 4 and 5 had inhibition against four tested cancer cell lines, KB, Hep-G2, Lu-1 and MCF-7 with IC 50 values from 2.0 to $14.6 \mu \mathrm{g} / \mathrm{mL}$ (Table 3). Other compounds had weak or no cytotoxicity against these four tested cancer cell lines.

Table 2. Antimicrobial activities of compounds 1-10 ( $\left.\mathrm{IC}_{90}: \mu \mathrm{g} / \mathrm{mL}\right)$.

\begin{tabular}{|c|c|c|c|c|c|c|c|c|}
\hline Compd. & E. faecalis & S. aureus & B. cereus & E. coli & P. aeruginosa & S. enterica & C. albicans & M. tuberculosis \\
\hline 2 & 1 & 1 & 1 & $>256$ & 1 & 8 & 1 & $>50$ \\
\hline 4 & 32 & 32 & 16 & 128 & 32 & 32 & 32 & 6.0 \\
\hline 5 & $>256$ & $>256$ & $>256$ & $>256$ & $>256$ & $>256$ & $>256$ & 11.1 \\
\hline 6 & $>256$ & $>256$ & $>256$ & 128 & $>256$ & $>256$ & $>256$ & $>50$ \\
\hline 9 & $>256$ & $>256$ & $>256$ & $>256$ & $>256$ & $>256$ & $>256$ & $>50$ \\
\hline 10 & 32 & nt & nt & 128 & nt & nt & 64 & $>50$ \\
\hline Strep & 256 & 256 & 128 & 32 & 256 & 128 & nt & nt \\
\hline Cyclohex & nt & nt & nt & nt & nt & nt & 32 & nt \\
\hline
\end{tabular}

Strep: Streptomycin; Cyclohex: Cyclohexamide; nt: not tested.

Table 3. Cytotoxic activity of compounds 1-10 $\left(\mathrm{IC}_{50}: \mu \mathrm{g} / \mathrm{mL}\right)$.

\begin{tabular}{ccccc}
\hline Compd & KB & Hep-G2 & Lu-1 & MCF-7 \\
\hline $\mathbf{1}$ & 59.7 & 32.0 & 80.0 & 71.7 \\
$\mathbf{2}$ & 118.4 & $>128$ & $>128$ & $>128$ \\
$\mathbf{3}$ & $>128$ & $>128$ & $>128$ & $>128$ \\
$\mathbf{4}$ & 4.8 & 2.27 & 4.0 & 14.5 \\
$\mathbf{5}$ & 2.0 & 2.0 & 4.8 & 11.8 \\
$\mathbf{6}$ & 47.3 & 78.4 & 71.5 & 60.0 \\
$\mathbf{7}$ & $>128$ & 56.0 & $>128$ & $>128$ \\
$\mathbf{8}$ & $>128$ & $>128$ & $>128$ & $>128$ \\
$\mathbf{9}$ & $>128$ & $>128$ & $>128$ & $>128$ \\
Ellipticine & $0.3 \pm 0.05$ & $0.3 \pm 0.05$ & $0.4 \pm 0.05$ & $0.5 \pm 0.05$ \\
\hline
\end{tabular}

\section{Materials and Methods}

\subsection{General Experimental Procedures}

Optical rotations were recorded on a Polax-2L polarimeter in MeOH. HR-ESIMS were recorded on a FT-ICR 910-MS TQFTMS-7 T mass spectrometer. CD spectra were taken on a Chirascan CD spectrometer. IR spectra were recorded on a Nicolet Impact 410 FT-IR spectrometer, and NMR spectra on a Bruker AM500 MHz spectrometer operating at $125.76 \mathrm{MHz}$ for ${ }^{13} \mathrm{C} \mathrm{NMR}$, and at $500.13 \mathrm{MHz}$ for 
${ }^{1} \mathrm{H}$ NMR. ${ }^{1} \mathrm{H}$ chemical shifts were referenced to $\mathrm{CD}_{3} \mathrm{OD}$ at $\delta 3.31 \mathrm{ppm}$, while the ${ }^{13} \mathrm{C}$ chemical shifts were referenced to the central peak at $\delta 49 \mathrm{ppm}$. For HMBC experiments the delay (1/2J) was $70 \mathrm{~ms}$.

\subsection{Actinomycete Material}

The actinomycete strain G248 was obtained from the Halichondria panicea (Pallas, 1766) sponge (sponge taxonomy was identified by Prof. Do Cong Thung, Institute of Marine Environment and Resources-Vietnam Academy of Science and Technology), collected in Son-Tra island (Da Nang) - Vietnam in August 2016. A voucher specimen was deposited at the Institute of Marine Environment and Resources, Vietnam Academy of Science and Technology (VAST).

The strain G248 was isolated from above-mentioned sponge sample. The taxonomy of the strain G248 was identified by using $16 \mathrm{~S}$ rRNA gene sequence analysis. Its gene sequence was registered with GenBank access code MG917690 (Figure S3). On the basis of morphological and phylogenetic evidence (Figures S1 and S2), the actinomycete strain G248 was assigned to the genus Streptomyces.

\subsection{Fermentation and Extraction}

Strain G248 was activated and inoculated into $1 \mathrm{~L}$ of A1 medium pH 7.0 comprising starch $(5.0 \mathrm{~g})$, yeast extract $(2.0 \mathrm{~g})$, peptone $(1.0 \mathrm{~g})$ and artificial sea salt $(30.0 \mathrm{~g})$ in $1.0 \mathrm{~L}$ of distilled water. After 7 days of incubation at $28{ }^{\circ} \mathrm{C}$ with agitation, the culture broth was used to inoculate the fermentation in $50 \mathrm{~L}$ of high-nutrient medium A1 ${ }^{+}$(soluble starch: $10 \mathrm{~g} / \mathrm{L}$; yeast extract: $4 \mathrm{~g} / \mathrm{L}$; peptone: $2 \mathrm{~g} / \mathrm{L}$; instant ocean: $30 \mathrm{~g} / \mathrm{L} ; \mathrm{CaCO}_{3}: 1 \mathrm{~g} / \mathrm{L}$; agar: $15 \mathrm{~g} / \mathrm{L}$; add water to $\left.1 \mathrm{~L}, \mathrm{pH} 7.0\right)$. The fermentation was incubated at $28^{\circ} \mathrm{C}$ with agitation of $200 \mathrm{rpm}$ and harvested on the tenth day.

\subsection{Isolation and Purification}

The fermentation broth $(50 \mathrm{~L})$ was passed through a XAD-16 column (10 kg XAD-16). The column was washed with distilled water $(70 \mathrm{~L})$, followed by eluting with methanol $(80 \mathrm{~L})$. The methanol solution was concentrated under reduced pressure. The crude extract (12.6 g) was purified by column chromatography $(\mathrm{CC})$ on silica gel, eluted with $\mathrm{CH}_{2} \mathrm{Cl}_{2} / \mathrm{EtOH}$ gradient to give 11 fractions. Fraction F4 (1.23 g) was separated by CC on Sephadex LH-20 $\left(\mathrm{CH}_{2} \mathrm{Cl}_{2} / \mathrm{MeOH}\right.$ : 9/1), providing 4 subfractions. Subfraction F4.3 (90 mg) was purified by CC on silica gel (0 to $50 \% \mathrm{MeOH}$ in $\mathrm{CH}_{2} \mathrm{Cl}_{2}$ ) to furnish compounds 7 (5 mg). Fraction F5 (1.72 g) was subjected to CC on silica gel (0 to $100 \% \mathrm{MeOH}$ in $\mathrm{CH}_{2} \mathrm{Cl}_{2}$ ), leading to four subfractions. Subfraction F5.3 (305 mg) was separated by CC on silica gel, eluted with a $\mathrm{CH}_{2} \mathrm{Cl}_{2}$ /acetone gradient, providing 4 sub-subfractions. Sub-subfraction F5.3.4 was chromatographed on silica gel, eluted with EtOAc/MeOH gradient, giving compounds 6 (5 mg) and 8 (15 mg). Fraction F6 (550 mg) was purified by CC on silica gel (0 to $100 \% \mathrm{MeOH}$ in $\mathrm{CH}_{2} \mathrm{Cl}_{2}$ ) providing 4 subfractions. Subfraction F6.4 (1.16 g) was separated by CC on Sephadex LH-20 (MeOH/CH${ }_{2} \mathrm{Cl}_{2}$ : 9/1), followed by preparative thin-layer chromatography (TLC) $\left(\mathrm{CH}_{2} \mathrm{Cl}_{2} / \mathrm{MeOH}: 8.5 / 1.5\right)$ to furnish compounds $9(3.9 \mathrm{mg})$. Fraction $9(360 \mathrm{mg})$ was separated by CC on Sephadex LH-20 $\left(\mathrm{MeOH} / \mathrm{CH}_{2} \mathrm{Cl}_{2}\right.$ : 9/1), leading to 7 subfractions. Subfraction F9.5 $(35 \mathrm{mg})$ was purified by CC on silica gel (0 to $100 \%$ $\mathrm{MeOH}$ in EtOAc), followed by preparative TLC (EtOAc/MeOH: 8/2) to furnish compound 10 (5.9 mg). Fraction 10 (1.62 g) was separated by CC on silica gel (0 to $100 \% \mathrm{MeOH}$ in $\mathrm{CH}_{2} \mathrm{Cl}_{2}$ ), furnishing six subfractions. Subfraction F10.2 (55 mg) was subjected to CC on Sephadex $\mathrm{LH}-20\left(\mathrm{MeOH} / \mathrm{CH}_{2} \mathrm{Cl}_{2}: 9 / 1\right)$, followed by preparative TLC $\left(\mathrm{CH}_{2} \mathrm{Cl}_{2} /\right.$ acetone: $\left.7 / 3\right)$ to yield compounds $\mathbf{1}(2.5 \mathrm{mg})$ and $\mathbf{5}(3.7 \mathrm{mg})$. Subfraction F10.4 (40 mg) was chromatographed on Sephadex LH-20 column (MeOH/ $\left.\mathrm{CH}_{2} \mathrm{Cl}_{2}: 9 / 1\right)$, affording compounds $2(3.0 \mathrm{mg})$ and $3(6.0 \mathrm{mg})$. Finally, subfraction F10.5 $(70 \mathrm{mg})$ was subjected to CC on Sephadex $\mathrm{LH}-20\left(\mathrm{MeOH} / \mathrm{CH}_{2} \mathrm{Cl}_{2}: 9 / 1\right)$, followed by preparative TLC $\left(\mathrm{CH}_{2} \mathrm{Cl}_{2} /\right.$ acetone: $\left.7 / 3\right)$ to afford compound $4(3.9 \mathrm{mg})$.

\subsection{Spectral Data}

(2S,2"S)-6-lavandulyl-7,4'-dimethoxy-5,2'-dihydroxylflavanone (1)—amorphous yellow solid; $[\alpha]_{\mathrm{D}}{ }^{25}$ -5 (c 0.176, $\mathrm{MeOH}) ; \mathrm{R}_{\mathrm{f}}: 0.7\left(\mathrm{CH}_{2} \mathrm{Cl}_{2}-\mathrm{MeOH}, 8.5: 1.5\right) ; \mathrm{IR}(\mathrm{KBr}): 3366,2916,1696,1497,1457,1411,1376$, 
1278, 1151, 1093, 974, $886 \mathrm{~cm}^{-1} ;{ }^{1} \mathrm{H}$ NMR $\left(\mathrm{CD}_{3} \mathrm{OD}, 500 \mathrm{MHz}\right)$ and ${ }^{13} \mathrm{C} \mathrm{NMR}\left(\mathrm{CD}_{3} \mathrm{OD}, 125 \mathrm{MHz}\right)$, Table 1; CD (MeOH) nm $(\Delta \varepsilon)$ : 205 (-10.2), 225 (+12.8), 259 (+0.7), 291 (-7.7), 337 (+3.6); HR-ESI-MS $m / z 453.2270[\mathrm{M}+\mathrm{H}]^{+}$(calcd. for $\left.\mathrm{C}_{27} \mathrm{H}_{33} \mathrm{O}_{6}, 453.2277\right)$.

(2S,2"S)-6-lavandulyl-5,7,2', $4^{\prime}$-tetrahydroxylflavanone (2)-amorphous yellow solid; $[\alpha]_{\mathrm{D}}{ }^{25}+3$ (c 0.2, MeOH); $\mathrm{R}_{\mathrm{f}}: 0.45\left(\mathrm{CH}_{2} \mathrm{Cl}_{2}-\mathrm{MeOH}, 8.5: 1.5\right)$; IR (KBr): 3261, 2961, 2921, 1631, 1604, 1514, 1439, $1382,1296,1162,1083,974,887 \mathrm{~cm}^{-1} ;{ }^{1} \mathrm{H}$ NMR $\left(\mathrm{CD}_{3} \mathrm{OD}, 500 \mathrm{MHz}\right)$ and ${ }^{13} \mathrm{C} \mathrm{NMR}\left(\mathrm{CD}_{3} \mathrm{OD}, 125 \mathrm{MHz}\right)$, Table 1; $\mathrm{CD}(\mathrm{MeOH}) \mathrm{nm}(\Delta \varepsilon): 204(-6.5), 220(+8.4), 258(+0.6), 291(-5.9), 315(+0.8) ;$ HR-ESI-MS m/z $425.1960[\mathrm{M}+\mathrm{H}]^{+}$(calcd. for $\left.\mathrm{C}_{25} \mathrm{H}_{29} \mathrm{O}_{6}, 425.1964\right)$.

(2"S)-5'-lavandulyl-2'-methoxy-2,4,4', $6^{\prime}$-tetrahydroxylchalcone (3)-amorphous yellow solid; $[\alpha]_{\mathrm{D}}{ }^{25}$ -1.8 (c 0.54, MeOH); $\mathrm{R}_{\mathrm{f}}: 0.33\left(\mathrm{CH}_{2} \mathrm{Cl}_{2}-\mathrm{MeOH}, 8.5: 1.5\right)$; IR (KBr): 3695, 2925, 2854, 1605, 1546, 1449, 1233 , $1141,1104 \mathrm{~cm}^{-1} ;{ }^{1} \mathrm{H}$ NMR $\left(\mathrm{CD}_{3} \mathrm{OD}, 500 \mathrm{MHz}\right)$ and ${ }^{13} \mathrm{C}$ NMR $\left(\mathrm{CD}_{3} \mathrm{OD}, 125 \mathrm{MHz}\right)$, Table $1 ; \mathrm{CD}(\mathrm{MeOH})$ $\mathrm{nm}(\Delta \varepsilon): 212(+0.9), 259(+0.5), 291(-0.2), 319(+0.06)$; HR-ESI-MS $m / z 439.2117[\mathrm{M}+\mathrm{H}]^{+}$(calcd. for $^{2}$ $\left.\mathrm{C}_{26} \mathrm{H}_{31} \mathrm{O}_{6}, 439.2121\right)$.

\subsection{Antimicrobial Activity Assay}

Antimicrobial assays were carried out using E. coli (ATCC25922), P. aeruginosa (ATCC27853), S. enterica (ATCC12228), E. faecalis (ATCC13124), S. aureus (ATCC25923), B. cereus (ATCC13245), and C. albicans (ATCC1023). Stock solutions of samples were prepared in DMSO, and the antimicrobial assays were carried out in 96-well microtiter plates against the microbial strains $\left(5 \times 10^{5} \mathrm{CFU} / \mathrm{mL}\right)$ using a modification of the published method [28]. After incubation for $24 \mathrm{~h}$ at $37^{\circ} \mathrm{C}$, the absorbance at $650 \mathrm{~nm}$ was measured using a microplate reader. Streptomycin and nystatin were used as reference compounds.

\subsection{Anti-Mycobacterial Activity Assay}

M. tuberculosis H37Rv (ATCC 27294) was purchased from American Type Culture Collection (ATCC). These strains were cultured to late log phase in Middlebrook 7H9 broth supplemented with $0.2 \%(\mathrm{vol} / \mathrm{vol})$ glycerol, $0.05 \%$ Tween $^{\mathrm{TM}} 80$, and $10 \%(v / v)$ oleic acid-albumin-dextrose-catalase (OADC). The culture was harvested and resuspended in phosphate-buffered saline. Suspensions were then filtered through $8 \mu \mathrm{m}$ filter membranes and frozen at $-80^{\circ} \mathrm{C}$. Prior to use of bacterial stocks for the anti -TB assay, colony-forming units (CFUs) were determined by plating on 7H11 agar media. The MIC is defined here as the lowest concentration resulting in $\geq 90 \%$ growth inhibition of the bacteria relative to untreated controls. MIC against replicating $M$. tuberculosis was measured by the Microplate Alamar Blue Assay (MABA) in 7H12 media [29].

\subsection{Cytotocicity Assay}

An MTT assay was used to determine the cytotoxic activity of compounds $\mathbf{1 - 1 0}$ with human cancer cell lines (KB, LU-1, Hep-G2 and MCF-7) acquired from the American Type Culture Collection (ATCC, Manassas, VA) using a modification of the published method [30]. Cells were cultured in medium RPMI 1640 supplemented with 10\% FBS (fetal bovine serum) under a humidified atmosphere of $5 \% \mathrm{CO}_{2}$ at $37^{\circ} \mathrm{C}$. Compounds $\mathbf{1}-\mathbf{1 0}$ were dissolved in DMSO at a concentration of $20 \mathrm{mg} / \mathrm{mL}$. A series of dilutions for each compound was prepared to final concentrations of 128, 32, 8, 2 and 0.5 $\mathrm{mg} / \mathrm{mL}$. Samples $(100 \mu \mathrm{L})$ of the complexes with different concentrations were added to the wells on 96-well plates. Cells were separated with trypsin and ethylenediaminetetraacetic acid (EDTA), and seeded in each well with $3 \times 10^{4}$ cells per well. An MTT solution $(20 \mu \mathrm{L}, 4 \mathrm{mg} / \mathrm{mL})$ of phosphate buffer saline $\left(8 \mathrm{~g} \mathrm{NaCl}, 0.2 \mathrm{~g} \mathrm{KCl}, 1.44 \mathrm{~g} \mathrm{Na}_{2} \mathrm{HPO}_{4}\right.$ and $0.24 \mathrm{~g} \mathrm{KH}_{2} \mathrm{PO}_{4}$ per $\mathrm{L}$ ) was added to each well after being incubated for $48 \mathrm{~h}$. The cells were further incubated for $4 \mathrm{~h}$ and a purple formazan precipitate was formed, which was separated by centrifugation. The precipitate was dissolved by adding DMSO $(100 \mu \mathrm{L})$ to each well. The optical density of the solution was determined by a plate reader (TECAN) at $540 \mathrm{~nm}$. The inhibition ratio was achieved on the basis of the optical densities from the calculation of three replicate tests. 
Supplementary Materials: The following are available online at http://www.mdpi.com/1660-3397/17/9/529/s1, Figure S1: Morphological appearance of strain G248, Figure S2: Gel electrophoresis of PCR product, Figure S3: 16S rRNA gene sequence of Streptomyces sp. G248 on GenBank, Figure S4: Optimized conformers of (2S,2" R)-1, Figure S5: Optimized conformers of $\left(2 S, 2^{\prime \prime} S\right)-1$, Figure S6: Optimized conformers of $\left(2 S, 2{ }^{\prime \prime} R\right)-2$, Figure S7: Optimized conformers of $(2 S, 2$ " $S)-2$, Figure S8: Optimized conformers of (2"S)-3, Figure S9: ${ }^{1} \mathrm{H}$ NMR spectrum of 1 (500 $\left.\mathrm{MHz}, \mathrm{CD}_{3} \mathrm{OD}\right)$, Figure S10: ${ }^{13} \mathrm{C}$ NMR spectrum of $1\left(125 \mathrm{MHz}, \mathrm{CD}_{3} \mathrm{OD}\right)$, Figure S11: ${ }^{1} \mathrm{H}-{ }^{1} \mathrm{H}$ COSY spectrum of 1 (500 MHz, CD $\left.{ }_{3} \mathrm{OD}\right)$, Figure S12: HSQC spectrum of $1\left({ }^{1} \mathrm{H}: 500 \mathrm{MHz},{ }^{13} \mathrm{C}: 125 \mathrm{MHz}, \mathrm{CD}_{3} \mathrm{OD}\right)$, Figure S13: HMBC spectrum of $1\left({ }^{1} \mathrm{H}: 500 \mathrm{MHz},{ }^{13} \mathrm{C}: 125 \mathrm{MHz}, \mathrm{CD}_{3} \mathrm{OD}\right)$, Figure S14: ROESY spectrum of $1\left(500 \mathrm{MHz}, \mathrm{CD}_{3} \mathrm{OD}\right)$, Figure S15: HR-ESI-MS of 1, Figure S16: IR spectrum of 1, Figure S17: CD spectrum of 1, Figure S18: ${ }^{1} \mathrm{H}$ NMR spectrum of 2 (500 MHz, CD $3 \mathrm{OD})$, Figure S19: ${ }^{13} \mathrm{C}$ NMR spectrum of 2 (125 MHz, CD $\left.3 \mathrm{OD}\right)$, Figure S20: ${ }^{1} \mathrm{H}_{-}{ }^{1} \mathrm{H}$ COSY spectrum of $2\left(500 \mathrm{MHz}, \mathrm{CD}_{3} \mathrm{OD}\right)$, Figure S21: HSQC spectrum of $2\left({ }^{1} \mathrm{H}: 500 \mathrm{MHz},{ }^{13} \mathrm{C}: 125 \mathrm{MHz}, \mathrm{CD}_{3} \mathrm{OD}\right)$, Figure S22: HMBC spectrum of $2\left({ }^{1} \mathrm{H}: 500 \mathrm{MHz},{ }^{13} \mathrm{C}: 125 \mathrm{MHz}, \mathrm{CD}_{3} \mathrm{OD}\right)$, Figure S23: ${ }^{1} \mathrm{H}$ NMR spectrum of 2 (500 MHz, DMSO- $\left.d_{6}\right)$, Figure S24: ROESY spectrum of 2 (500 MHz, DMSO- $\left.d_{6}\right)$, Figure S25: HR-ESI-MS of 2, Figure S26: IR spectrum of 2, Figure S27: CD spectrum of 2, Figure S28: ${ }^{1} \mathrm{H}$ NMR spectrum of $3\left(500 \mathrm{MHz}, \mathrm{CD}_{3} \mathrm{OD}\right)$, Figure S29: ${ }^{13} \mathrm{C}$ NMR spectrum of $3\left(125 \mathrm{MHz}, \mathrm{CD}_{3} \mathrm{OD}\right)$, Figure S30: ${ }^{1} \mathrm{H}^{-1} \mathrm{H}$ COSY spectrum of $3\left(500 \mathrm{MHz}, \mathrm{CD}_{3} \mathrm{OD}\right)$, Figure S31: HSQC spectrum of $3\left({ }^{1} \mathrm{H}: 500 \mathrm{MHz},{ }^{13} \mathrm{C}: 125 \mathrm{MHz}, \mathrm{CD}_{3} \mathrm{OD}\right)$, Figure S32: HMBC spectrum of $3\left({ }^{1} \mathrm{H}\right.$ : $\left.500 \mathrm{MHz},{ }^{13} \mathrm{C}: 125 \mathrm{MHz}, \mathrm{CD}_{3} \mathrm{OD}\right)$, Figure S33: ${ }^{1} \mathrm{H}-\mathrm{NMR}$ spectrum of 3 (500 MHz, DMSO- $d_{6}$ ), Figure S34: ROESY spectrum of 3 (500 MHz, DMSO- $d_{6}$ ), Figure S35: HR-ESI-MS of 3, Figure S36: IR spectrum of 3, Figure S37: CD spectrum of 3, Table S1. Conformational population (\%) for the most stable conformers of (2S,2" $R)-1$, Table S2. Conformational population (\%) for the most stable conformers of $\left(2 S, 2^{\prime \prime} S\right)-1$, Table S3. Conformational population $(\%)$ for the most stable conformers of $(2 S, 2$ "R)-2, Table S4. Conformational population (\%) for the most stable conformers of $(2 S, 2$ "S)-2, Table S5: Conformational population (\%) for the most stable conformers of (2"S)-3.

Author Contributions: V.C.P., B.T.M., V.M.C. and H.D.T.M., contributed to the co design of the study and wrote the manuscript. D.D.C., T.T.V.T, D.T.T and V.N.V. performed experiments and analyzed data. Q.V.T., M.A.N. and T.T.D. did the isolation and identification of the actinomyces. H.M.L. performed the antimicrobial activity assay. S.C., R.M. and G.S. performed anti-TB assay. All authors contributed to the manuscript revision, and read and approved the submitted version.

Funding: This research was financially supported by the Survey of Marine Resources and Environmental Management Program of Vietnam (Program 47, Grant number VAST.ĐA47.12/16-19), and by the Fogarty International Center of the National Institutes of Health under Award Number D43TW010530. The content is solely the responsibility of the authors and does not necessarily represent the official views of the National Institute of Health.

Conflicts of Interest: The authors declare no conflicts of interest.

\section{References}

1. Laport, M.S.; Santos, O.C.S.; Muricy, G. Marine sponges: Potential sources of new antimicrobial drugs. Curr. Pharm. Biotechnol. 2009, 10, 86-105. [CrossRef] [PubMed]

2. El-Demerdash, A.; Tammam, M.A.; Atanasov, A.G.; Hooper, J.N.A.; Al-Mourabit, A.; Kijjoa, A. Chemistry and biological activities of the marine sponges of the genera Mycale (Arenochalina), Biemna and Clathria. Mar. Drugs 2018, 16, 214. [CrossRef] [PubMed]

3. Thomas, T.R.A.; Kavlekar, D.P.; LokaBharathi, P.A. Marine drugs from sponge-microbe association-A review. Mar. Drugs 2010, 8, 1417-1468. [CrossRef] [PubMed]

4. Hardoim, C.C.P.; Costa, R. Microbial communities and bioactive compounds in marine sponges of the family Irciniidae-A review. Mar. Drugs 2014, 12, 5089-5122. [CrossRef] [PubMed]

5. Das, S.; Mangwani, N. Ocean acidification and marine microorganisms: Responses and consequences. Oceanologia 2015, 57, 349-361. [CrossRef]

6. Brinkmann, C.M.; Marker, A.; Kurtböke, D.I. An overview on marine sponge-symbiotic bacteria as unexhausted sources for natural product discovery. Diversity 2017, 9, 40. [CrossRef]

7. Romano, S.; Jackson, S.A.; Patry, S.; Dobson, A.D.W. Extending the "one strain many compounds" (OSMAC) principle to marine microorganisms. Mar. Drugs 2018, 16, 244. [CrossRef]

8. Balasubramanian, S.; Othman, E.M.; Kampik, D.; Stopper, H.; Hentschel, U.; Ziebuhr, W.; Oelschlaeger, T.A.; Abdelmohsen, U.R. Marine sponge-derived Streptomyces sp. SBT343 extract inhibits staphylococcal biofilm formation. Front. Microbiol. 2017, 8, 236. [CrossRef]

9. Watve, M.G.; Tickoo, R.; Jog, M.M.; Bhole, B.D. How many antibiotics are produced by the genus Streptomyces. Arch. Microbiol. 2001, 176, 386-390. [CrossRef] 
10. Subramani, R.; Aalbersberg, W. Marine actinomycetes: An ongoing source of novel bioactive metabolites. Microbiol. Res. 2012, 167, 571-580. [CrossRef]

11. Assia, M.; Hasnaa, A.; Sara, M.; Jamal, M.; Menggad, M. Physico-chemical characterization of a pink red-like pigments produced by five new bacterial soil strains identified as Streptomyces coelicoflavus. Am. J. Microbiol. Res. 2018, 6, 67-72. [CrossRef]

12. Igarashi, Y.; Rakicidin, D. An inhibitor of tumor cell invasion from marine-derived Streptomyces sp. J. Antibiot. 2010, 63, 563-565. [CrossRef] [PubMed]

13. Sarmiento-Vizcaino, A.; Espadas, J.; Martin, J.; Brana, A.F.; Reyes, F.; Garcia, L.A.; Blanco, G. Atmospheric precipitations, hailstone and rainwater, as a novel source of Streptomyces producing bioactive natural products. Front. Microbiol. 2018, 9, 773. [CrossRef] [PubMed]

14. Ha, T.J.; Yang, M.S.; Jang, D.S.; Choi, S.U.; Park, K.H. Inhibitory activities of flavanone derivatives isolated from Sophora flavescens for melanogenesis. Bull. Korean Chem. Soc. 2001, 22, 97-99.

15. Jung, M.J.; Kang, S.S.; Jung, H.A.; Kim, G.J.; Choi, J.S. Isolation of flavonoids and a cerebroside from the stem bark of Albizzia julibrissin. Arch. Pharmacal Res. 2004, 27, 593-599. [CrossRef]

16. Berova, N.; Di-Bari, L.; Pescitelli, G. Application of electronic circular dichroism in configurational and conformational analysis of organic compounds. Chem. Soc. Rev. 2007, 36, 914-931. [CrossRef] [PubMed]

17. Bringmann, G.; Bruhn, T.; Maksimenka, K.; Hemberger, Y. The assignment of absolute stereostructures through quantum chemical circular dichroism calculations. Eur. J. Org. Chem. 2009, 2717-2727. [CrossRef]

18. Frisch, M.J.; Trucks, G.W.; Schlegel, H.B.; Scuseria, G.E.; Robb, M.A.; Cheeseman, J.R.; Scalmani, G.; Barone, V.; Mennucci, B.; Petersson, G.A.; et al. Gaussian 09; Revision C.01, Gaussian: Wallingford, CT, USA, 2009.

19. Gaffield, W. Circular dichroism, optical rotatory dispersion and absolute configuration of flavanones, 3-hydroxyflavanones and their glycosides: Determination of aglycone chirality in flavanone glycosides. Tetrahedron 1970, 26, 4093-4108. [CrossRef]

20. Cao, D.D.; Do, T.Q.; Doan, T.M.H.; Vu, T.Q.; Le, T.H.M.; Tran, D.T.; Chau, V.M.; Do, C.T.; Pham, V.C. Antimicrobial lavandulylated flavonoids from a sponge-derived actinomycete. Nat. Prod. Res. 2018. [CrossRef]

21. Parsons, I.C.; Gray, A.I.; Waterman, P.G. New triterpenes and flavonoids from the leaves of Bosistoa brasii. J. Nat. Prod. 1993, 56, 46-53. [CrossRef]

22. Yomosa, K.; Hirota, A.; Sakai, H.; Isogai, A. Isolation of harman and norharman from Nocardia sp. and their inhibitory activity against plant seedlings. Agric. Biol. Chem. 1987, 51, 921-922. [CrossRef]

23. Rosa, E.B. ${ }^{13} \mathrm{C}$ NMR spectra of substituted carbazoles and azacarbazoles ( $\beta$-carbolines). Magn. Reson. Chem. 1988, 26, 1109-1113.

24. Fdhila, F.; Vazquez, V.; Sanchez, J.L.; Riguera, R. Diketopiperazines. Antibiotics active against Vibrio anguillarum isolated from marine bacteria associated with cultures of Pecten maximus. J. Nat. Prod. 2003, 66, 1299-1301. [CrossRef] [PubMed]

25. Wang, G.; Dai, S.; Chen, M.; Wu, H.; Xie, L.; Luo, X.; Li, X. Two diketopiperazine cyclo(Pro-Phe) isomers from marine bacterium Bacillus subtilis sp. 13-2. Chem. Nat. Compd. 2010, 46, 583-585. [CrossRef]

26. Wang, L.; Zheng, C.D.; Li, X.J.; Gao, J.M.; Zhang, X.C.; Wei, G.H. Cyclo(Pro-Tyr) from an endophytic rhizobium isolated from Glycyrrhiza uralensis. Chem. Nat. Compd. 2012, 47, 1040-1042. [CrossRef]

27. Komin, S.; Gossens, C.; Tavernelli, I.; Rothlisberger, U.; Sebastiani, D. NMR solvent shifts of adenine in aqueous solution from hybrid QM/MM molecular dynamics simulations. J. Phys. Chem. B 2007, 111, 5225-5232. [CrossRef] [PubMed]

28. Andrews, J.M. Determination of minimum inhibitory concentrations. J. Antimicrob. Chemother. 2001, 48, 5-16. [CrossRef]

29. Cho, S.; Lee, H.S.; Franzblau, S. Microplate alamar blue assay (MABA) and low oxygen recovery assay (LORA) for Mycobacterium tuberculosis. Methods Mol. Biol. 2015, 1285, 281-292.

30. Mosmann, T. Rapid colorimetric assay for cellular growth and survival: Application to proliferation and cytotoxicity assays. J. Immunol. Methods 1983, 65, 55-63. [CrossRef]

(C) 2019 by the authors. Licensee MDPI, Basel, Switzerland. This article is an open access article distributed under the terms and conditions of the Creative Commons Attribution (CC BY) license (http://creativecommons.org/licenses/by/4.0/). 